\title{
Gastrointestinal helminths of West African Dwarf (WAD) goats in Ido Local Government Area, Ibadan, Oyo State, Nigeria
}

\author{
Unigwe C. R. ${ }^{{ }^{*}}$, Balogun, F. A. ${ }^{2}$, Olona, J. F. ${ }^{2}$, Nwufoh, O. C. ${ }^{2}$ and Odah, I. S. ${ }^{2}$ \\ ${ }^{1}$ Department of Veterinary Animal Health and Production, University of Nigeria, Nsukka, Nigeria. \\ ${ }^{2}$ Federal College of Animal Health and Production Technology, Ibadan, Nigeria. \\ *Corresponding author. Email: robinsonunigwe@gmail.com
}

Copyright () 2017 Unigwe et al. This article remains permanently open access under the terms of the Creative Commons Attribution License 4.0, which permits unrestricted use, distribution, and reproduction in any medium, provided the original work is properly cited.

Received 24th August, 2016; Accepted 25th September, 2016

\begin{abstract}
A study on the prevalence of fecal helminth parasites in adult WAD goats was carried out in five different areas of Ido Local Government Area of Oyo State, Nigeria. The objectives of the study were to determine the prevalence of fecal helminth parasites of goats in some areas including Gbekuba, Adabeji, Adifase, Owode and Lade-Owo as well as the genera distribution of faecal helminth parasites of goats in the study area. A total of 22 faecal samples per area were collected summing up to 110 samples from 110 goats. Simple floatation technique was used to identify eggs of parasites in the faecal samples and the eggs examined under light microscope for typing. Out of the 110 fecal samples, $78(70.91 \%)$ of them were positive for helminth endo-parasites including five genera of nematodes: Ascaris spp (56.36\%), Strongyloides spp (2.73\%), Trichuris spp (0.91\%), Nematodirus spp (2.73\%) and Trichostrongylus spp $(1.82 \%)$ and a genus of trematode: Fasciola spp (6.36\%). The results showed that Ascaris spp was the most prevalent followed by Fasciola spp, Trichuris spp, Nematodirus spp, Strongyloides spp and Trichostrongylus spp. It is therefore recommended that routine deworming should be embraced using broad spectrum anthelmintics particularly against nematodes and trematodes to bring to minimal or possibly stamp out endo-parasites from the study area.
\end{abstract}

Key words: Deworming, faecal helminths, floatation technique, goats, prevalence.

\section{INTRODUCTION}

Goats are very important domestic animals. The importance of goat husbandry includes, goats reared for the provision of meat and milk for human consumption and raw materials for industries (Devendra and Meleroy, 2001). The breeds of goat found in Nigeria are Sahel, West African Dwarf (WAD) and Red Sokoto or Maradi (Ajala, 1998). Small ruminants form an integral part of the cultural life and farming system of Nigeria peasantry. Goat production in Nigeria is essentially a traditional activity in which household units feature prominently (Ajala, 1998). Despite the high small ruminant population in developing countries particularly in Africa, their prolificacy, cheap production cost and the indiscriminate demand for their product, goat production potential remains poorly exploited, due largely to neglect, disease, lack of motivation on the part of decision makers and the conservative traditional management system (Ajala,1998). Ruminant animals have been the major source of meat in Nigeria. Relative to other ruminants, goats are easier to keep and require smaller capital investment (Momoh et al., 1998).

Goats are important domestic animals in the tropical livestock production system. In subsistence sector, pastoralists and agriculturists often depend on them for much of their livelihood (Devendra and Meloroy, 2001). Goat, being a small sized ruminant is capable of integrating itself into dissimilar socio-economic situation prevailing in our country. Despite indiscriminate slaughtering 
of goats, the total population keeps increasing due to its prolificacy in producing more than one young one per kidding and of short generation interval. Being prolific breeders, the unique ability of the goat, kidding twice in 14 months and of producing several female kids in eight years cannot be achieved either by a cow or buffalo in their life period (Gopalakrishman and Mohanyal, 1991). The importance of goat in the rural economy is evidenced by its unparalleled economic traits, ability to get acclimatized under diversified agro-climatic conditions, unfastidious choosing of available forage, high fertility and short generation interval, practically no religious restriction to goat and its products among the diversified religious people in rural area (Gopalakrishman and Mohanyal, 1991).

Although small ruminants represent a great resource for the nation, the productivity per animal is low. Small ruminant diseases, poor management and lesser efforts provided to improve the performance of the animals are to be responsible for the reduced productivity (Ademosun, 1992). Stomach worms affect especially camels, goats and sheep. Different types of worms are transmitted when an animal eats grass or drinks water contaminated with larva or eggs. The problem is especially common in the rainy season (IIRR, 1996). Historically, gastrointestinal helminthes infestations have been associated with great economic losses to farmers throughout the world, these losses manifest through morbidity in acute cases and in chronic infections, reduced weight gains, reduced food conversion, abortion, infertility, reduced meat and milk production (Ogunrinade, 1984; Karki, 1987). These parasites are very ubiquitous and have also remained the major constraint, hindering the efficiency of rearing cattle and goats successfully (Khin-Khin, 2007; Siddiki et al., 2009). The negative impact of helminthes infections on livestock productivity in tropical countries has long been established. Reports by Ndarathi et al. (1989), Olusi (1997) and Edosomwan and Ewarami (2012) contained recent appraisals of this problem. The helminth infestations of ruminants are mostly caused by Nematodes (such as Ostertagia spp, Capillaria spp, Trichuris spp, Strongyliodes spp); Cestodes (such as Moniezia spp, Taenia spp) and Trematodes (such as Dicrocoelium spp, Fasciola gigantica, Amphistomes) (Zahid et al., 2005). According to Regassa et al. (2006) ruminants infected by gastro intestinal helminthes parasites cause loss to farmers through; low milk production, low fertility, reduced work capacity, involuntary culling, treatment cost, mortality and reduction in the market value of infected animals. Helminthosis is one of the important parasitic diseases contributing to losses in productivity (Agyei, 2003; Odoi et al., 2007).

Worldwide, parasitic helminthes are a major cause of losses in productivity and health problems of goats and sheep and are usually associated with huge economic losses especially in resource poor regions of the world
(Cernanska et al., 2005). Parasitic helminthes also cause immuno-suppression and as a result enhance susceptibility to other diseases (Kumba et al., 2003; Torina et al., 2004; Githigia et al., 2005). The problem is much more severe in tropical countries due to very favorable environmental conditions for parasite transmission, poor nutrition of host animals and poor sanitation in facilities where animals are housed. As a result, diseases caused by helminthes remain one of the major impediments to small ruminant's production in the tropics (Maichomo et al., 2004; Kumsa and Abebe, 2009). In the tropics, up to $95 \%$ of sheep and goats are reported to be infected with helminthes of which Haemonchus and Trichostrongylus are the two most commonly involved genera (Opara et al., 2005; Odoi et al., 2007; Mbuh et al., 2008). However, the majority of the animals infected with helminthes do not show clinical signs owing to the chronic nature of the disease. Subclinical signs helminthosis is considered the most common form of infection and cause of economic losses (Opara et al., 2005). This work was designed to estimate the array of Genera of parasites as well as level of their prevalence in the study area.

\section{MATERIALS AND METHODS}

\section{Experimental site}

The experiment was conducted at Ido Local Government Area of Oyo State, Nigeria. This is located between $7^{\circ} 45 \mathrm{~N}, 7^{\circ} 15 \mathrm{~N}$ and $3^{\circ} 30 \mathrm{E}, 3^{\circ} 50 \mathrm{E}$ and covers $986 \mathrm{~km}^{2}$, located in the forest belt zone and characterized by two distinct seasons: the dry season which lasts from November to March and the rainy season which starts from April and ends in October. It enjoys abundant rainfall of over $1800 \mathrm{~mm}$ annually. It has relatively high humidity and average daily temperature ranges between $25^{\circ} \mathrm{C}$ and $35^{\circ} \mathrm{C}$ almost throughout the year. The vegetation pattern consists of rainforest in the south and guinea savannah in the north (Oluwabunmi and Ayoade, 2014).

\section{Experimental animals, materials, duration and procedure}

One hundred and ten fecal samples were collected randomly from mixed-sex adult West African Dwarf (WAD) goats reared within Ido LGA, Oyo State, Nigeria between March and April, 2013. The study was conducted for a period of 5 weeks. Feces were collected from the rectum of the goats using sterile procedure (Urguhart et al., 1996) at different geographical areas within the metropolis. The feces were put in separate sample bottles which were labeled appropriately. The samples were then immediately taken to the laboratory for analysis for the presence of parasites eggs and oocysts. The method employed was the simple floatation 
Table 1. Prevalence of faecal helminth parasites of goats in Ido Local Government Area of Oyo State.

\begin{tabular}{lcc}
\hline Location & No Examined & No Infected (\%) \\
\hline Gbekuba & 22 & $13(11.82)$ \\
Adabeji & 22 & $16(14.55)$ \\
Adifase & 22 & $14(12.73)$ \\
Owode & 22 & $13(11.82)$ \\
Lade-Owo & 22 & $22(20.00)$ \\
Total & 110 & $78(70.91)$ \\
\hline
\end{tabular}

Table 2. Genera prevalence of faecal helminth parasites of goats in Ido Local Government Area of Oyo State.

\begin{tabular}{lcccccc}
\hline \multirow{2}{*}{ Genus spp } & \multicolumn{7}{c}{ Number infected (\%) } \\
\cline { 2 - 7 } & Gbekuba & Adabeji & Adifase & Owode & Lade-Owo & Total \\
\hline Ascaris & $11(10)$ & $10(9.09)$ & $9(8.18)$ & $12(10.91)$ & $20(18.18)$ & $62(56.36)$ \\
Trichuris & 0 & $1(0.91)$ & 0 & 0 & 0 & $1(0.91)$ \\
Trichostrongylus & $1(0.91)$ & $1(0.91)$ & 0 & 0 & 0 & $2(1.82)$ \\
Strongyloides & $1(0.91)$ & 0 & $1(0.91)$ & $1(0.91)$ & 0 & $3(2.73)$ \\
Fasciola & 0 & $4(3.64)$ & $2(1.82)$ & 0 & $1(0.91)$ & $7(6.36)$ \\
Nematodirus & 0 & 0 & $2(1.82)$ & 0 & $1(0.91)$ & $3(2.73)$ \\
Total & $13(11.82)$ & $16(14.55)$ & $14(12.73)$ & $13(11.82)$ & $22(20)$ & $78(70.91)$ \\
\hline
\end{tabular}

technique as described by Foryet (2001). Simple floatation is based on the assumption that helminth eggs will float to the surface of the floatation medium (Saline water) which has a higher specific gravity than the eggs. About 2 to $3 \mathrm{~g}$ of the feces was crushed using a sterilize swab stick to break the feces, which in most cases was in pellets so as to give a solution. After obtaining homogenous mixture, it was sieved and placed in a test tube. The coarse debris was then trapped on gauze. The test tube containing the homogenous mixture was then placed in the centrifuge machine for about 5 mins at 1200 rpm. The floatation medium ( $\mathrm{NaCl}$ solution) was then added to the filtrate and filled to the brim until a convex meniscus was formed on the test tube. A cover slip was then placed and left for about 3 mins. After then, the cover slip was pulled gently from the test tube and placed on a slide ready for viewing under low power magnification of a compound microscope.

\section{Statistical Analysis}

Descriptive statistics was used to analyze the results by calculating the percentage positivity of gastrointestinal parasites.

\section{RESULTS AND DISCUSSION}

The prevalence of fecal helminth parasites of goats in some sampled locations in Ido L. G. A of Oyo State is as shown in Table 1. Out of 110 samples of goat feces randomly collected at Gbekuba, Adabeji, Adifase, Owode and Lade-Owo and examined parasitologically in the laboratory, the prevalence rates of $13(11.82 \%)$, $16(14.55 \%), \quad 14(12.73 \%), \quad 13(11.82 \%)$ and $22(20 \%)$ respectively were got giving a total of $78(70.91 \%)$ as the overall prevalence rate in the study area (Table 1).

Table 2 shows the genera distribution of helminth parasites of goats in the study area. The following helminth parasites were observed using qualitative and quantitative microscopic examinations of the faecal samples. These include Ascaris spp, Trichuris spp, Trichostrongylus spp, Strongyloides spp, Fasciola spp and Nematodirus spp with their prevalence rates as $56.36 \%, 0.91 \%, 1.82 \%, 2.73 \%, 6.36 \%$ and $2.73 \%$ respectively (Table 2). The result showed that Ascaris spp had the highest prevalence rate of $56.36 \%$ followed by Fasciola spp (6.36\%), Strongyloides spp (2.73\%), Nematodirus spp (2.73\%), Trichostrongylus spp (1.82\%), and Trichuris spp $(0.91 \%)$ respectively.

Faecal helminth parasites were present in the five (5) geographical areas sampled in Ido Local Government Area of Oyo State, Nigeria with an overall prevalence of $70.91 \%$ (78 out of 110 animals) and local prevalences of $11.82 \%, 14.55 \%, 12.73 \%, 11.82 \%$ and $20 \%$ out of 22 animals/location at Gbekuba, Adabeji, Adifase, Owode and Lade-Owo respectively (Table 1 ). The overall prevalence rate of $70.91 \%$ is lower than the results of 
Hassan (1964), Getachew (1998), Hailelul (2002) and Nath et al. (2011) who reported prevalence rates of $82.1 \%, 96.38 \%, 84.32 \%$ and $94.67 \%$ respectively in goats while Silva et al. (2010) also observed a parasite frequency of $94.5 \%$ among sheep. However, the result of the present study is similar to those obtained by other researchers (Genene, 1994; Tesfaye, 1998; Abebe and Esayasu, 2001; Hailelue, 2002; Amenu, 2005; Regassa et al., 2006; Sissay et al., 2007; Ahid et al., 2008; Tefera et al., 2011; Kumsa et al., 2011; Vanessa et al., 2014). In contrast, the finding is higher than reports of Assoku (1981) in Ghana and Vercruysee (1985) in Senegal, Patel et al. (2001) who recorded $54.92 \%$ in goats in India, $65.5 \%$ got by Osakwe and Anyigor, (2007) in goats in Ikwo L.G.A. of Ebonyi State, Nigeria, Raza et al. (2007) that reported the infection rate of GIT helminths in goats as $52 \%$ in Southern Punjab, India, ljaz et al. (2008) who reported $63.33 \%$ in Lahore, Pakistan, Shimelis et al. (2011) that found $47.67 \%$ in sheep and goats in North Gondar zone, Northwest Ethiopia, prevalence of 55.47\% $(n=213)$ in goats and overall prevalence of $61.4 \%(384$ goats and 384 sheep) in both sheep and goats (Tesfaheywet, 2012), Kuchai et al., (2012) who reported $31.42 \%$ in Pashima goats of Ladakh, India, and Elele et al. (2013) that reported $62.1 \%$ in cattle.

The low prevalence could be due to the period in which the research was carried out which coincided to end of dry season when moisture and high humidity which support multiplication and growth of parasites were still low. Similarly, high ambient temperature and low humidity that characterized the period could have drastically reduced the number of parasites through desiccation in the study area. This is in consonance with the assertions of Lima (1998) and Andrews (1999) that unfavorable environmental factors hinder development and growth of most helminth species. Equally, Banks et al. (1990), Tembely et al. (1998) and Waruiru et al. (2005) stated that most helminth species are susceptible to desiccation in dry climatic conditions that results from the high temperature at which even eggs fail to develop into $L_{3}$. Another probable reason is that goats prefer to browse shrubs (Taylor, 1985) which might reduce the infection rate by reducing larval consumption during grazing. Immunological response of goats for helminth infection is limited compared to sheep (Urquhart et al., 1996). The findings of this work is in a harmony with different researchers (Regassa et al., 2006; Keyyu et al., 2006; Raza et al., 2007) who have found a direct influence of grazing characteristics on the prevalence of most of gastrointestinal helminths. There existed direct relationship between moisture and prevalence of parasitosis (Regassa et al., 2006) while desiccation suppresses the development and growth of parasite (Dagnachew et al., 2011) thereby reducing the infection rate. Furthermore, management system (Regassa et al., 2006) could also contribute in the difference in the prevalence as well as medicaments. It has also been observed that sheep mostly have a higher prevalence of GIT parasites than the goats which is in agreement with other previous works (Teklye, 1991; Waruiru et al., 2005; Asif et al., 2008) and this is assumed to be due to the grazing habit of the sheep where they graze closer to the ground fostering opportunity of exposure to parasites (Tesfaheywet, 2012). Also the genera prevalences of $56.36 \%, 0.91 \%, 1.82 \%, 2.73 \%, 6.36 \%$ and $2.73 \%$ for Ascaris spp, Trichuris spp, Trichostrongylus spp, Strongyloides spp, Fasciola spp and Nematodirus spp respectively was contrary to Hailelul (2002) who reported species prevalence rates of $36.04 \%$ (Trichuris spp), $12.86 \%$ (Fasciola spp), 8\% (Trichostrongylus spp), and $6.42 \%$ (Strongyloides spp) in goats reared around Wollaita, Asella and Soddo areas in Kombolcha in Ethiopia as well as $1.71 \%$ for fasciolosis in cattle reported by Unigwe and Nwakpu (2006) at Bodija Abattoir, Ibadan, Nigeria. The result is however similar in respect of Trichuris spp in pigs at Bodija Abattoir, Ibadan, where a finding of $0.99 \%$ was found (Okorafor et al., 2014). The results of this study have also shown that nematodes are the most common helminth parasites of goats in the study area which was in line with the result of Hailelul (2002).

\section{Conclusion and recommendation}

The extensive grazing system, inadequate and irregular deworming as well as ignorance have all combined with other factor bordering on immunity and malnutrition to conspire against eradication of this menace. It is therefore imperative to recommend quarterly (three monthly) deworming with broad spectrum anthelminthics to help reduce losses associated with helminthosis. In the same vein, regular spraying of pastures with potent parasiticides is also recommended. Similarly, ruminants on pasture should be given nutritious supplements regularly to boost their immunity against parasites.

\section{CONFLICT OF INTEREST}

The authors declare that they have no conflict of interest.

\section{REFERENCES}

Abebe, W., \& Esayasu, G. (2001). Survey on ovine and caprine gastro-intestinal helminthosis in eastern part of Ethiopia during the dry season of the year. Rev. Vet. Med., 152(5), 379-384.

Ademosun, A. A. (1992). Constraints and prospects for small ruminant's research and development in Africa. Small. Rum. Dev. Afr., 2, 1-5.

Agyei, A. D. (2003). Epidemiological Studies on gastrointestinal parasitic infections of lambs in the coastal savanna regions of Ghana. Trop. Anim. Health Prod., 35, 207-217. 
Ahid, S. M. M., Suassuna, A. C. D., Maia, M. B., Costa, V. M. M., \& Soares, H. S. (2008). Parasitos gastrintestinais em caprinos e ovinos da regiao Oeste do Rio Grande do Norte, Brasil. Ciênc Anim Bras, 9(1), 212-218.

Ajala, M. K. (1998). Household's decision making in small ruminant's production in Giwa Local Government Area of Kaduna State, Nigeria. In; Proc. Silver Jubilee Anniversary Conference of NSAP March 21-26, 536.

Amenu, A. (2005). Epidemiology of gastrointestinal tract nematodes of small ruminants in three differentAgro Ecological zones of Southern Ethiopia. MSC Thesis. Faculty of Veterinary Medicine, Addis Ababa University, Debre-Zeit. Ethiopia, p. 99.

Andrews, S. J., (1999). The life cycle of Fasciola hepatica. In: Dalton JP (ed) Fasciolosis. CAB, Wallingford, Pp 1-29.

Asif, M., Azeem, S., Asif, S., \& Nazir, S. (2008). Prevalence of Gastrointestinal Parasites of Sheep and Goats in and around Rawalpindi and Islamabad, Pakistan. J. Vet. Anim. Sci., 1, 14-17.

Assoku, K. G. (1981). Studies of Parasitic Helminthes of sheep and goats in Ghana. Bulletin of Animals Health and Production in Africa, 29, 1-10.

Banks, D. J. D., Singh, R., Barger, I. A., Pratap, B., \& Le Jambre, L. F., (1990). Development and survival of infected larvae of Haemonchus contortus and Trichostrongylus colubriformis on pastures in a tropical environment. Int. J. Parasitol., 20(2), 155-60.

Cernanska, D., Varaday, M., \& Corba, J. (2005). The occurrence of sheepgastrointestinal parasites in the Slovak Republic. Bulletin of Animal Health and Production in Africa. Helminthologia, 42, 205- 209.

Dagnachew, S., Amamute, A., \& Temegen, W. (2011). Epidemiology of gastrointestinal helminthiasis ofsmall ruminants in selected sites of North Gondar zone, Northwest Ethiopia. Ethiop. Vet. J., 15 (2), 57-68

Devendra, C., \& Meleroy, G. B. (2001). Goat and Sheep production in the tropics. Longman press, Bureaux 1-183.

Edosomwan, E. U., \& Ewarami, T. J. (2012). Ticks and helminth parasites of cattle at Ikpoba hill abattoir Benin-City, Edo State, Nigeria. Biological and Environmental Sciences Journal for the Tropics, 9(1), 179-183.

Elele, K., Owhoeli, O., \& Gboeloh, L. B. (2013). Prevalence of species of helminthes parasites in cattle slaughtered in selected abattoirs in Port Harcourt, South-south, Nigeria. International Research on Medical Sciences, 1(2), 10-17.

Foryet, J. W. (2001). Veterinary Parasitology: Reference Manual.5th ed. Blackwell Inc. India.38-39.

Genene, R. (1994). A study of prevalence of ovine GIT helminthes in and around kombolcha. DVM Thesis, faculty of veterinary medicine, Addis Ababa University, Debre Zeit. Ethiopia, Pp. 24-25.

Getachew, G. (1998). Prevalence of ovine and caprine GIT helminthes in Mekele and its surrounding. DVM Thesis, Faculty of Veterinary Medicine, Addis Ababa University, Debrezeit, Ethiopia, p. 260.

Githigia, S. M., Thamsborg S. M., Maingi, N., \& Munyva, W. K. (2005). The epidemiology of gastrointestinal nematodes in goats in the low potential areas of Thika district, Kenya. Bull. Anim. Health Prod. Afr., 53, 5-12.

Gopalakrishman, C. A., \& Mohanyal, G. (1991). Livestock and Poultry Enterprises for rural development. Vikas publishing house Pvt. New Delhi, India. Pp. 399-406.

Hailelul, N. (2002). Study on prevalence of GIT helminthes of small ruminants in and around Wolayta Soddo, southern Ethiopia. DVM Thesis, Faculty of veterinary medicine, Addis Ababa university, Debre-Zeit. Ethiopia, p. 353.

Hassan, Z. (1964). Investigation into the intestinal helminths load in local goats. Indian Vet J., 41, 543-546.

International Institute of Rural Reconstruction (IIRR) (1996). Ethno veterinary medicine in Kenya. Field manual of traditional animal health care practices. Pp. 115-116.

ljaz, M., Khan, M. S., Avais, M., Ashraf, K., \& Ali, M. M. (2008). Infection rate and chemotherapy of various helminths in goats in and around Lahore. Pakistan Veterinary Journal, 28(4), 167-170.

Karki, N.P.S. (1987). Sheep resources in Nepal and some constraints in migratory system of production. Paper presented at the $2^{\text {nd }}$ conference of the Nepal veterinary association pp 23-25.

Keyyu, J.D., Kassuku, A.A., Msalilwa, L.P., Monrad, J. and Kyvsgaard, N.C., (2006). Cross-sectional prevalence of helminth infections in cattle on traditional, smallscale and large-scale dairy farms in Iringa district, Tanzania. Vet. Res. Commun., 30, 45-55

Khin-Khin, L. (2007). Prevalence of Cryptosporidia,gardia and other gastrointestinalparasites of dairy calves in Mandalay, Myannar. Chuang mai University Berlin 98.

Kuchai, J. A., Chishti, M. Z., Tak, H., \& Lone, B. A. (2012). Faecal Examinations of Pashmina Goats (Capra siberica) of Ladakh for Nematode Infections. Global Journal of Science Frontier Research Biological Sciences, 12(4), 37-40.

Kumba, F. F., Katjivena, G., \& Lutaaya, E. (2003). Seasonal evolution of fecal egg output by gastrointestinal worms in goats on commercial farms in eastern Namibia. Onderstepoort J. Vet. Res. 70, 265-271.

Kumsa, B., \& Abebe, G. (2009). Multiple anthelmintic resistance on a goat farm in Hawassa (Southern Ethiopia). Trop. Anim. Health. Prod., 41, 655-662.

Kumsa, B., Tadesse, T., Sori, T., Dugum, R., \& Hussen, B. (2011). Helminths of sheep and goats in Central Oromia (Ethiopia) during the dry season. J. Anim. Vet. Adv., 10(14), 1845-1849.

Lima, W. S. (1998). Seasonal infection pattern of gastrointestinal nematodes of beef cattle in Minas Gerais State-Brazil. Vet. Parasitol., 74, 203-214.

Maichomo, M. W., Kagira, J. M., \& Walker, T. (2004). The point prevalence of gastrointestinal parasites in calves, sheep and goats in Magadi division, SouthWestern Kenya. Onderstepoort J. Vet. Res., 71, 257-261.

Mbuh, J. V., Ndamukong, K. J. N., Ntonifor, N., \& Nforlem, G. F. (2008). Parasites of sheep and goats and their prevalence in Bokova, a rural area of Buea Sub-Division, Cameroon. Vet. Parasitol., 156, 350-352.

Momoh, S., Ayinde, J. A., \&d Salawu, K.B. (1998). Animal protein supply. A study of Goat marketing in Kwara State. In Proc. Silver Anniversary Conference of NSAP pp 131-132.

Nath, B., Roy, K., Shaikat, A. and Shil, S. (2011). A study on prevalence and pathological effects of intestinal helminthes in black Bengal Goats in Chittagong. YYU Veteriner Fakultesi Dergisi, 22(3), 139-142.

Ndarathi, C. M., Wagghela, S., \& Semenye, P. P. (1989). Helminthiasis in Masan Ranches in Kenya. Bulletin of Animal Health and Production in Africa, 37, 205-208.

Odoi, A., Gathuma, J. M., Gachuiri, C. K., \& Omore, A. (2007). Risk factors of gastrointestinal nematode parasite infections in small ruminants kept in small holder mixed farms in Kenya. 
BMC Vet. Res., 3, 6-16.

Ogunrinade, A. F. (1984). A response in natural and experimental infections of cattle with Fasciola gigantica in West Africa Dwarf sheep goats. Tropical Animal Health Production, 16(3), 161-166.

Okorafor, U. P., Unigwe, C. R., Okorafor, J. C., Isegbe, E. I., Ogbu, U. M. and Atoyebi, T. J. (20014). A Survey of Gastrointestinal Parasites of Pigs that Arrived for Slaughter at Bodija Abattoir, Ibadan, Oyo State, Nigeria. Int. J. Appl. Sci., 20(2), 53-57.

Olusi, T. A. (1997). The prevalence of liver helminth parasites of ruminants in Maiduguri, Bornu State, Nigeria. Bulletin of Animal Health and Production in Africa, 44, 151-154.

Oluwabunmi, D., \& Ayoade, O. (2014). Land Use Change Analysis in a Derived Savannah of South-Western Nigeria and Challenges for Agricultural Land. J. Biol., Agric. And Healthcare, 4(18), 68-75.

Opara, M. N., Nwaobasi, J. K. \& Okoli, I. C. (2005). Occurrence of parasitic helminthes among ruminants reared under traditional husbandry system in Owerri, South East Nigeria. Bull. Anim. Health Prod. Afr., 53, 226-233.

Osakwe, I. I. and Anyigor, S. I. (2007). Prevalence of gastrointestinal helminths in west African dwarf (WAD) goats in an agrarian agro-ecosystem. Animal Research International, 4(3), 728 - 732.

Patel, M. D., Nauriyal, D. S., Hasnani, J. J., \& Gupta, R. S. (2001). Prevalence of gastrointestinal parasitism in goats maintained under semi-intensive and field management systems. Indian J. Vet. Med., 21, 99-101.

Raza, M. A., Iqbal, Z., Jabbar, A., \& Yaseen, M. (2007). Point prevalence of gastrointestinal helminthiasis in ruminants in southern Punjab. Pakistan J. Helminthol., 81, 323-328.

Regassa, F., Teshale, S., Reta, D., \& Yosef, K. (2006). Epidemiology of gastrointestinal parasites of ruminants in Western Oromia, Ethiopia. Intl. J. Appl. Res. Vet. Med., 4(1), 51-57.

Shimelis, D., Asmare, A., \& Wudu, T. (2011). Epidemiology of gastrointestinal helminthiasis of small ruminants in selected sites of North Gondar zone, Northwest Ethiopia. Ethiop. Vet. J., 15 (2), 57-68.

Siddiki, A. Z., Uddin, M. B., Hasan, M. B., Hossain, M. F., Rahman, M. M., Sarker, M. S., \& Hossain, M. A. (2009). Coproscopic and Haematological approaches to determine the prevalence of helminthiasis and protozoan diseases of Red Chittagong Cattle (RCC) breed in Bangladesh. Pakistan veterinary Journal, 30(1), 1-6.

Silva, M. R. L., Sousa, E. A., Bonelli, E. A., Medeiros, M. O., Silva, G. F., \& Queiroz, E. O. (2010). Parasitas gastrintestinais de ovinos criados na regiao de RondonopolisMT. Rev. Biod., 9(1), 67-73.

Sissay, M. M. (2007). Epidemiology and seasonal dynamics of gastrointestinalnematodes infections of sheep in a semi- arid region of Eastern Ethiopia. Veterinary Parasitology 143, 311321.

Taylor, C. A., (1985). Multispecies Grazing Research Overview (Texas). In: Proceedings of a conference on multispecies grazing. June 25-28, 1985, Winrock International, Morrilton, AR, 65-68.
Tefera, M., Batu, G., \& Bitew, M. (2011) Prevalence of Gastrointestinal Parasites of Sheep and Goats in and Around Bedelle, South-Western Ethiopia. Internet J. Vet. Med., 8, 25.

Teklye, B. (1991). Epidemiology of endoparasites of small ruminants in sub-saharan Africa. Proceedings of Fourth National Livestock Improvement Conference. Addis Ababa, Ethiopia, pp. 13-15. November 7-11.

Tembely, S., Lahlou-Kassi, K.and Rege, J.E. (1998). Breed and season effects on the peri-parturient rise in nematode egg output in indigenous ewes in a cool tropical environment. Vet Parasitol. 77(2-3), 123-132.

Tesfaheywet, Z. (2012). Helminthosis of sheep and goats in and around Haramaya, Southeastern Ethiopia. Journal of Veterinary Medicine and Animal Health, 4(3), 48-55.

Tesfaye, H. (1998). Ovine and bovine helminthiasis in Kelala (S. Wollo). Ethiopian Veterinary Association Proceedings of the 12th Conference. Addis Ababa, Ethiopia, June, pp30-34.

Torina, A., Dara, S., Marino, A. M. F., Sparagano, O. A. E., Viatale, F., \& Caracappa, S. (2004). Study of gastrointestinal nematodes in Sicillian sheep and goats. Ann. N.Y. Acad. Sci., 1026,187-194.

Unigwe, C. R., \& Nwakpu, P. E. (2006). Liver Condemnation in Cattle: A Case Study of Bodija Abattoir, Ibadan, Nigeria. J. Res. Agric., 3(2), 14-18.

Urquhart, G. M., Aremour, J., Dunchan, J. L., Dunn, A. M., \& Jeninis, F. W. (1996). Veterinary parasitology 2nd edition. The University of Glasgow, Blackwell Sciences, Scotland, pp. 3-137.

Vanessa, D. V., Vinicius L. R. V., Thais, F. F., Ana, C. R. A., Sergio, S. A., Diego, V. O. S., Gian, L. S., \& Lidio, R. B. M. (2014). Sheep gastrointestinal helminthiasis in the Sertão region of Paraíba State, Northeastern Brazil: prevalence and risk factors. Braz. J. Vet. Parasitol. Jaboticabal., 23(4), 488494.

Vercruysee, J. (1985). The seasonal prevalence of inhibited development of Haemonchus contortus in Senegal. Verterinary Parasitology, 17, 159 - 163.

Waruiru, R. M., Mutune, M. N., \& Otieno, R. O., (2005). Gastrointestinal parasite infections of sheep and goats in a semi-arid area of Machakos District, Kenya. Bull. Anim. Health Prod. Afr., 53(1), 25-34.

Zahid, I. A., Latif, M., \& Baloch, K. B. (2005). Incidence of endoparasites in exotic cattle calves. Pakistan Veterinary Journal, 25(1), 47-48. 